\title{
TOKSISITAS EKSTRAK KARANG LUNAK Cespitularia sp. DARI TELUK MANADO PROVINSI SULAWESI UTARA
}

\author{
(Toxicity of Soft Coral Extract Cespitularia sp. From Manado Bay \\ North Sulawesi)
Marsitasari Tandiongan ${ }^{1 \star}$, Robert A. Bara ${ }^{2}$, Esther D. Angkouw ${ }^{2}$, Fitje Losung ${ }^{2}$, Ping A. Angmalisang $^{2}$, Billy Th. Wagey ${ }^{2}$, Hariyani Sambali ${ }^{3}$ \\ 1. Mahasiswa Program Studi IImu Kelautan, FPIK, UNSRAT Manado \\ 2. Staf Pengajar Program Studi IImu Kelautan, FPIK, UNSRAT Manado \\ 3. Staf Pengajar Program Studi Budidaya Perairan, FPIK UNSRAT Manado \\ Penulis korespondensi: Marsita Tandiongan; marsitasrt@gmail.com
}

\begin{abstract}
Secondary metabolites produced by marine organisms commonly have unique chemical structures and very interesting pharmacological activities. Marine organisms that have the most chemical conent are produced by marine invertebrates, followed by marine plants. Groups that include marine invertebrates include: sponges, bryozoans, cnidarians and tunicates. Soft coral, which is one of the marine invertebrates, has biological activities, such as antifungal, cytotoxic, antineoplastic, antimicrobial, HIV inhibitor and anti-inflammatory. This study aims to determine the $\mathrm{LC}_{50}$ value of the soft coral extract Cespitularia sp. taken from Manado Bay by the Brine Shrimp Lethality Assay (BSLA) method. This toxicity test was carried out quantitatively by analyzing data based on the number of deaths caused by the test extract of Artemia sp. The results obtained based on data analysis namely the $\mathrm{LC}_{50}$ value of the soft coral extract Cespitularia sp. is $53.27 \mathrm{ppm}$, this means that the extract can be developed as an anticancer drug candidate due to below below to $1000 \mathrm{ppm}$. Soft coral Cespitularia sp. categorized as toxic based on the Meyer classification or moderately toxic based on the Tanamatayarat classification and very toxic based on the Clarkson classification.
\end{abstract}

Keywords: Soft coral; Cespitularia sp.; Toxicity; $\mathrm{LC}_{50}$

\begin{abstract}
ABSTRAK
Metabolit sekunder yang dihasilkan oleh organisme laut umumnya memiliki struktur kimia yang unik dan aktivitas farmakologi yang sangat menarik. Organisme laut yang mempunyai kandungan kimia terbanyak dihasilkan oleh invertebrata laut disusul kemudian oleh tumbuhan laut. Kelompok yang termasuk invertebrata laut antara lain: porifera, bryozoan, cnidaria dan tunikata. Karang lunak yang merupakan salah satu invertebrata laut, memiliki aktivitas biologi, seperti antifungal, sitotoksik, antineoplastik, antimikroba, inhibitor HIV dan anti inflamasi. Penelitian ini bertujuan untuk mengetahui nilai $\mathrm{LC}_{50}$ dari ekstrak karang lunak Cespitularia sp. yang diambil dari Teluk Manado dengan metode Brine Shrimp Lethality Assay (BSLA). Uji toksisitas ini dilakukan secara kuantitatif dengan melakukan analisis data berdasarkan jumlah kematian yang disebabkan oleh ekstrak uji pada larva udang Artemia sp. Hasil yang diperoleh berdasarkan analisis data yaitu nilai $\mathrm{LC}_{50}$ dari ekstrak karang lunak Cespitularia sp. sebesar 53,27 ppm, Hal ini berarti bahwa ekstrak tersebut dapat dikembangkan sebagai kandidat obat antikanker karena dibawah 1000ppm. Ekstrak karang lunak Cespitularia sp. dikategorikan toksik berdasarkan klasifikasi Meyer atau toksik sedang berdasarkan klasifikasi Tanamatayarat dan sangat toksik berdasarkan klasifikasi Clarkson.
\end{abstract}

Kata kunci; Karang lunak: Cespitularia sp.; Toksisitas; $\mathrm{LC}_{50}$ 


\section{PENDAHULUAN}

Indonesia merupakan negara dengan wilayah kepulauan yang luas di dunia dan memiliki wilayah laut yang sangat luas, dua pertiganya merupakan wilayah laut (Suparno, 2005). Laut Indonesia merupakan pusat keragaman terumbu karang dunia dan kaya akan sumber produk alami dengan struktur dan aktivitas biologis yang unik. Kandungan senyawa metabolit sekunder yang dimiliki oleh organisme laut menarik perhatian para peneliti, karena senyawa metabolit sekunder tersebut memiliki struktur kimia yang unik dan aktivitas farmakologis yang sangat menarik, seperti antikanker, antimikroba, antiinflamasi, antivirus, antifouling dan menghambat aktivitas enzim (Jiang, dkk., 2012; Kornprobst, 2010; Newman dan Cragg, 2009; Diyabalanage, dkk., 2012., Fattorusso, dkk., 2012, Bara, dkk. 2015, Mangindaan dan Taroreh, 2013). Makna ekologis dari senyawa metabolit sekunder salah satunya adalah sebagai perisai untuk melindungi diri dari musuh atau kompetitornya melawan predasi dan infeksi (Pawlik, 1993; Pisut \& Pawlik, 2002).

Organisme laut yang mempunyai kandungan kimia terbanyak dihasilkan oleh invertebrata laut disusul kemudian oleh tumbuhan laut. Kelompok yang termasuk invertebrata laut antara lain: porifera, bryozoa, cnidaria dan tunikata (Brauers, dkk., 2000). Karang lunak merupakan salah satu bagian dari kelompok hewan invertebrata pada ekosistem terumbu karang yang mengeluarkan zat tertentu yang bersifat toksik untuk melawan predasi (Huda, dkk. 2012). Zat yang dikeluarkan oleh karang lunak sebagai alat pertahanan diri tersebut merupakan jenis senyawa bioaktif. Senyawa bioaktif ini dapat berupa terpenoid, steroid dan steroid glikosida yang dapat dijadikan sebagai antibakteri patogen (antibakteri), sitotoksik, antineoplastik, antimikroba, inhibitor HIV dan anti inflamasi (Radhika, 2006; Gunawan, 2007). Salah satu metode awal yang sering dipakai untuk mengamati toksisitas senyawa dan merupakan metode penapisan untuk aktivitas antikanker senyawa kimia dalam suatu bahan ekstrak adalah Brine Shrimp Lethality Assay (BSLA). Suatu metode uji hayati yang tepat dan murah untuk skrining dalam menentukan toksisitas suatu ekstrak bahan alam dengan menggunakan hewan uji. (Irma, 2017). Lethal Concentration $50\left(\mathrm{LC}_{50}\right)$ adalah suatu perhitungan untuk menentukan keaktifan dari suatu ekstrak atau senyawa. Penggunaan $\mathrm{LC}_{50}$ ditujukan untuk uji ketoksikan suatu bahan dengan menggunakan larva udang sebagai hewan uji. Apabila nilai $\mathrm{LC}_{50}$ dengan metode BSLA pada suatu bahan ekstrak bersifat toksik maka bahan tersebut dapat dikembangkan sebagai obat antikanker (Carballo, 2002).

Keanekaragaman hayati laut Sulawesi Utara mencerminkan keanekaragaman kimiawi bahan alami bahari yang dikandungnya. Kelimpahan dan keanekaragaman kimia bahan alam dengan berbagai bioaktivitas potensial dapat dikembangkan ke tahap penemuan obat. Oleh sebab itu, penelitian ini bertujuan untuk mengetahui nilai $\mathrm{LC}_{50}$ ekstrak karang lunak Cespitularia sp. yang diambil dari Teluk Manado dengan menggunakan metode Brine Shrimp Lethality Assay.

\section{METODE}

\section{Lokasi Pengambilan Sampel}

Sampel karang lunak diambil di Teluk Manado, Kecamatan Malalayang, secara geografis terletak pada $1{ }^{\circ} 27^{\prime} 39.72 " \mathrm{~N}$ dan 12447'31.47"E. Peta lokasi pengambilan sampel tersaji pada Gambar 1. 


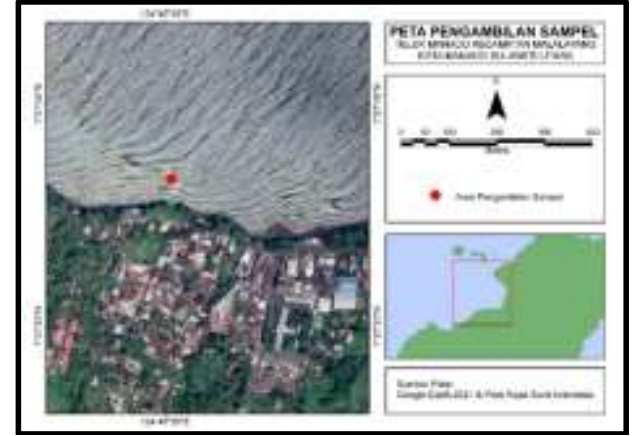

Gambar 1. Peta Lokasi

Pengambilan Sampel

\section{Identifikasi Sampel}

Identifikasi karang lunak dilakukan dengan cara mengamati morfologi sampel mulai dari bentuk, warna dan tekstur tubuh dan dipandu dengan buku Tropical Pasific Invertebrates (Colin and Charles, 1995).

\section{Ekstraksi}

Ekstraksi dilakukan dengan metode maserasi menggunakan pelarut

etil asetat. Sampel karang lunak Cespitularia sp. dibilas dengan air tawar terlebih dahulu, ditimbang lalu dipotong

kecil-kecil kemudian dimasukkan ke dalam botol aqua dan diberi label. Sampel karang lunak Cespitularia sp. direndam dengan pelarut etil asetat dan digoyang perlahan menggunakan pengaduk. Sampel kemudian dibilas dengan air tawar terlebih dahulu, ditimbang lalu dipotong kecil-kecil kemudian dimasukkan ke dalam botol aqua dan diberi label sampel. Perendaman dilakukan pada sampel dengan perbandingan 1:3 selama $1 \times 24$ jam sebanyak 2 kali pengulangan pada suhu ruangan. Setelah 24 jam, sampel disaring menggunakan kertas saring dan hasil saringan diuapkan dengan menggunakan evaporator dengan temperatur $40^{\circ} \mathrm{C}$ sampai tidak ada lagi pelarut yang menetes pada kondensator tube, lalu dimasukkan ke dalam falcon tube $50 \mathrm{~mL}$ menggunakan mikropipet 1000 $\mu \mathrm{L}$, sehingga diperoleh ekstrak pekat yang selanjutnya digunakan untuk pengujian sitotoksik.

\section{Penetasan Larva Artemia sp.}

Media untuk larva dibuat dengan menyaring air laut sebanyak 5 Liter. Penetasan kista dilakukan dalam wadah akuarium yang disekat bagian tengah sehingga menjadi 2 bagian, satu bagian ruang terang dan satu bagian gelap, dengan cara ditutup dengan kain hitam dan bagian yang lain dibiarkan terbuka. Artemia dimasukkan sebanyak 0,5 gram pada bagian yang gelap dan dibiarkan selama 48 jam sehingga telur menetas pada salinitas 34 ppt dan setelah 48 jam, larva siap digunakan untuk pengujian.

\section{Uji Toksisitas menggunakan metode Brine Shrimp Lethality Assay (BSLA) \\ Uji toksisitas dengan larva Artemia} sp. Leach mengikuti metode dalam Atta-ur-Rahman, dkk., (2005) yang telah dimodifikasi. Uji sitotoksik dilakukan sebanyak 3 kali pengulangan pada tiap-tiap konsentrasi. Ekstrak sampel karang lunak Cespitularia sp. dengan konsentrasi awal 100.000 ppm dibuat seri pengenceran. Seri pengenceran konsentrasi ekstrak uji dibuat 1000 ppm, 100 ppm, 50 ppm, 10 ppm, 1 ppm dengan pengambilan volume tertentu dari larutan stok menggunakan mikropipet lalu ditambahkan air laut. Larutan uji tersebut dimasukkan ke dalam masingmasing tabung reaksi sebanyak $5 \mathrm{~mL}$ dan ditambahkan 10 ekor larva. Kontrol negatif juga dibuat pada tabung reaksi yang berisi air laut dan 10 ekor larva tanpa penambahan ekstrak, lalu ditutup dengan menggunakan aluminium foil yang telah diberi lubang kecil dan dibiarkan selama 24 jam. Setelah 24 jam, dilakukan pengamatan 
terhadap kematian larva Artemia sp. Kriteria standar untuk mengukur kematian larva udang yaitu apabila larva udang tidak menunjukkan pergerakan selama pengamatan (Gambar 1.) (Cahyadi, dkk., 2009).

\section{Analisis Data}

Efek toksik diperoleh dari pengamatan dengan menghitung persen kematian (mortalitas) larva Artemia sp. pada tiap konsentrasi. Jumlah Artemia sp. yang mati dalam tiap tabung selama 24 jam dihitung. Persentase kematian larva kematian diperoleh dengan rumus:

$$
\% \text { Kematian }=\underset{\substack{100 \% \\ \text { jumlah larva uji }}}{\text { jumlarva mati }} \mathrm{x}
$$

Kemudian dibandingkan dengan kontrol dan dilakukan analisis hasil sehingga diperoleh harga $\mathrm{LC}_{50}$. Dari persen kematian, dicari nilai probit tiap kelompok hewan uji dengan mengacu pada Tabel Probit, dan dibuat dalam grafik fungsi dengan persamaan garis linear yaitu; $y=a+$ bx. Konsentrasi $\mathrm{LC}_{50}$ dihitung melalui persamaan yang diperoleh (Priyanto, 2009).

\section{HASIL DAN PEMBAHASAN}

\section{Identifikasi Sampel}

Hasil identifikasi didapatkan bahwa sampel tersebut merupakan karang lunak Cespitularia sp. dengan ciri-ciri berwarna kebiruan pada bagian luar, berwarna putih pada bagian dalam serta bertekstur lunak.

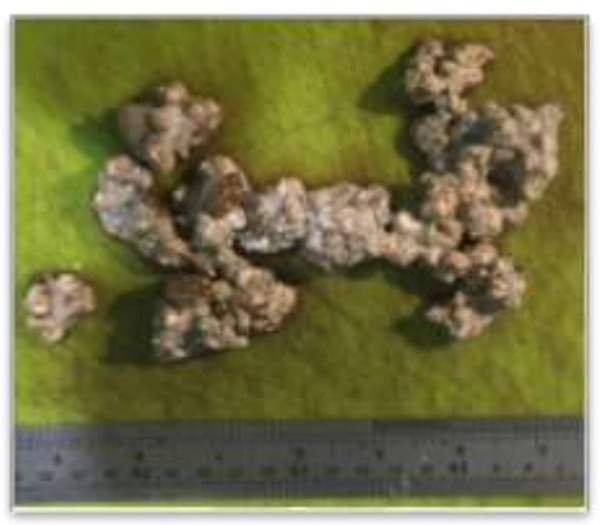

Gambar 2. Sampel karang lunak Cespitularia sp.

\section{Ekstraksi}

Sampel karang lunak dengan berat basah 76gr, diekstraksi dengan metode maserasi dan didapatkan ekstrak karang lunak Cespitularia sp. dengan berat $27,67 \mathrm{gr}$.

\section{Uji Toksisitas menggunakan metode Brine Shirmp Lethality Assay (BSLA)}

Hasil uji BSLA pada ekstrak karang lunak Cespitularia sp. (Tabel 1) diperoleh persamaan regresi linier (Gambar 3.) yaitu:

$$
\begin{aligned}
& \mathrm{Y}=2,1415+1,6556 \mathrm{x} \\
& 5=2,1415+1,6556 \mathrm{x} \\
& \mathrm{X}=(5-2,1415) / 1,6556 \\
& \mathrm{X}=1,7265 \\
& \mathrm{LC}_{50}=\text { Antilog } 1,796 \\
& \mathrm{LC}_{50}=53,27 \mathrm{ppm}
\end{aligned}
$$

Tabel 1. Hasil Perhitungan $\mathrm{LC}_{50}$ Ekstrak Karang Lunak Cespitularia sp.

\begin{tabular}{|c|c|c|c|c|c|c|}
\hline & \multicolumn{4}{|c|}{$\begin{array}{c}\text { Konsentrasi } \\
\text { Karang Lunak } \\
\text { Pengu } \\
\begin{array}{c}\text { langa } \\
\text { n }\end{array}\end{array}$} & \multicolumn{4}{|c|}{$\begin{array}{c}\text { Cespitularia sp. } \\
\text { (ppm) }\end{array}$} & $\begin{array}{c}\text { K } \\
(-)\end{array}$ \\
\cline { 2 - 6 } & 1 & 1 & 5 & 1 & 10 & \\
& 0 & 0 & 0 & 00 & \\
\hline I & 2 & 1 & 3 & 0 & 10 & 0 \\
\hline II & 0 & 1 & 0 & 1 & 10 & 0 \\
\hline III & 0 & 0 & 0 & 2 & 10 & 0 \\
\hline
\end{tabular}




\begin{tabular}{|c|c|c|c|c|c|c|}
\hline $\begin{array}{c}\text { Total } \\
\text { Kemat } \\
\text { ian }\end{array}$ & 2 & 2 & 3 & 3 & 30 & 0 \\
\hline $\begin{array}{l}\text { Rata- } \\
\text { rata }\end{array}$ & $\begin{array}{l}0 \\
6 \\
6\end{array}$ & $\begin{array}{l}0 \\
6 \\
6\end{array}$ & 1 & 1 & 10 & 0 \\
\hline $\begin{array}{c}\% \\
\text { Kemat } \\
\text { ian } \\
\text { Larva }\end{array}$ & 6 & 6 & $\begin{array}{l}1 \\
0\end{array}$ & $\begin{array}{l}1 \\
0\end{array}$ & $\begin{array}{c}10 \\
0\end{array}$ & 0 \\
\hline $\begin{array}{l}\text { Log } \\
\text { Konse } \\
\text { ntrasi }\end{array}$ & 0 & 1 & $\begin{array}{l}1 \\
6 \\
\end{array}$ & 2 & 3 & 0 \\
\hline $\begin{array}{l}\text { Nilai } \\
\text { Probit }\end{array}$ & $\begin{array}{l}4 \\
5\end{array}$ & $\begin{array}{l}3 \\
\text {, } \\
5 \\
\end{array}$ & $\begin{array}{l}3 \\
7 \\
7 \\
2 \\
\end{array}$ & $\begin{array}{l}3, \\
7 \\
2\end{array}$ & $\begin{array}{c}8,9 \\
5\end{array}$ & 0 \\
\hline $\mathbf{L C}_{50}$ & & & & & & \\
\hline
\end{tabular}

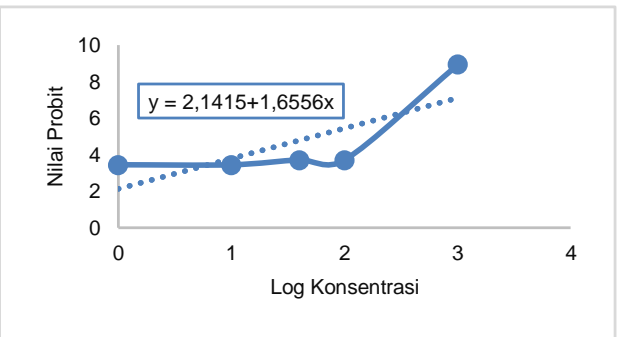

Gambar 3. Regresi Linier Karang Lunak Cespitularia sp.

Berdasarkan perhitungan tersebut, diperoleh nilai $\mathrm{LC}_{50}$ dari ekstrak karang lunak Cespitularia sp. sebesar 53,27 ppm. Pada penelitian sebelumnya, Priyatmoko (2008) melaporkan bahwa ekstrak karang lunak Sinularia sp. hasil transplantasi kedalaman $10 \mathrm{~m}$ mempunyai komponen yang bersifat toksik ditunjukkan dengan nilai $\mathrm{LC}_{50}$ sebesar 201,93 ppm. Werilolangi, melaporkan melaporkan bahwa ekstrak metanol Sinularia sp. memiliki sifat toksik dengan nilai $\mathrm{LC}_{50} \quad 5,98 \quad$ ppm dan Dendronephythya sp. memiliki sifat toksik dengan nilai $\mathrm{LC}_{50} 8,24 \mathrm{ppm}$ pada ekstrak methanol dan $\mathrm{LC}_{50}$ 9,02 ppm pada ekstrak kloroform.

Persentase kematian semakin meningkat dengan peningkatan konsentrasi larutan uji, untuk kelompok kontrol tidak terdapat larva
Artemia sp. yang mati. Kontrol negatif dilakukan untuk melihat apakah respon kematian hewan uji benar-benar berasal dari sampel dan bukan disebabkan oleh pelarut yang digunakan, sehingga dapat disimpulkan bahwa kematian pada larva Artemia sp. (Gambar 4.) murni disebabkan oleh ekstrak karang lunak Cespitularia sp.

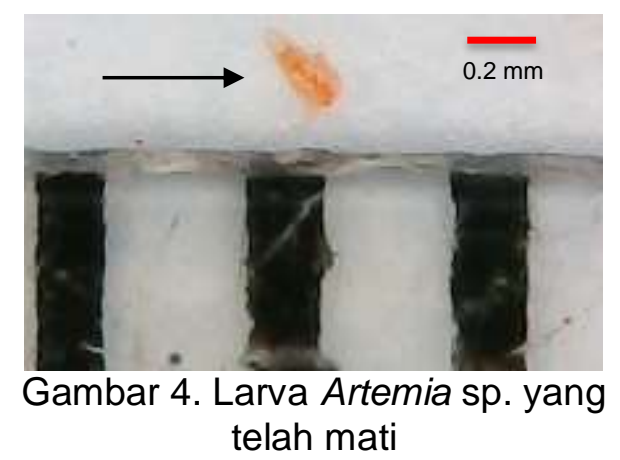

Ghisalberti (2008) menyatakan uji BSLA merupakan uji cepat dalam memprediksi aktivitas sitotoksik suatu senyawa/ekstrak dan terdapat hubungan yang positif antara toksisitas BSLA dan sifat sitotoksik suatu senyawa dengan beberapa macam sel. Rendahnya nilai $\mathrm{LC}_{50}$ pada ekstrak karang lunak Cespitularia sp. membuktikan bahwa ekstrak tersebut memiliki sifat toksik yang sangat kuat dan ekstrak berpotensi sebagai obat antikanker karena $\mathrm{LC}_{50}$ yang diperoleh ekstrak karang lunak Cespitularia sp. kurang dari 1000 ppm. Hal ini merujuk pada pernyataan Meyer, dkk., (1982) apabila nilai $\mathrm{LC}_{50}<1000$ ppm berarti ekstrak tersebut bersifat toksik dan nilai $\mathrm{LC}_{50}>1000$ ppm berarti ekstrak tersebut bersifat tidak toksik. Lebih spesifik diklasifikasikan oleh Tanamatayarat dan Clarkson (Tanamatayarat, 2016; Meena, dkk., 2020). Tingkat toksisitas menurut Tanamatayarat adalah sangat toksik $\left(\mathrm{LC}_{50}<10 \mathrm{ppm}\right)$, toksik sedang $\left(\mathrm{LC}_{50}\right.$ : 10-100 ppm), toksik lemah ( $\mathrm{LC}_{50}$ : 100-1000 ppm), dan tidak toksik ( $\mathrm{LC}_{50}$ $>1000$ ppm) (Tanamatayarat, 2016). Sedangkan klasifikasi toksisitas menurut Clarkson adalah jika $\mathrm{LC}_{50}$ di 
atas 1000 ppm (tidak toksik), $\mathrm{LC}_{50} 500$ - 1000 ppm (toksik rendah), $\mathrm{LC}_{50} 100$ $500 \mathrm{~g} / \mathrm{mL}$ (toksik sedang), dan $\mathrm{LC}_{50} 0$ 100 ppm (sangat toksik) (Meena, dkk., 2020). Berdasarkan persamaan regresi linier dari ekstrak tersebut, ekstrak karang lunak Cespitularia sp. dikategorikan toksik berdasarkan klasifikasi Meyer atau toksik sedang berdasarkan klasifikasi Tanamatayarat dan sangat toksik berdasarkan klasifikasi Clarkson Tanamatayarat dan sangat toksik berdasarkan klasifikasi Clarkson.

\section{KESIMPULAN}

Uji toksisitas dengan menggunakan metode Brine Shrimp Lethality Assay (BSLA) ekstrak karang lunak Cespitularia sp. menunjukkan nilai $\mathrm{LC}_{50}=53,27 \mathrm{ppm}$ dan berpotensi sebagai obat antikanker. Ekstrak karang lunak Cespitularia sp. dikategorikan toksik berdasarkan klasifikasi Meyer atau toksik sedang berdasarkan klasifikasi Tanamatayarat dan sangat toksik berdasarkan klasifikasi Clarkson.

\section{DAFTAR PUSTAKA}

Atta-ur-Rahman, Choudhary MI, Thomsen WJ. 2005. Bioassay Technique for Drug Development: Harwood academic publishers, Amsterdam.

Bara, R. A., G.D. Kandou, ARB. Ola, J. Posangi. 2015. Analisis Senyawa Antibiotik Dari Jamur Simbion Yang Terdapat Dalam Ascidian Didemnum molle Disekitar Perairan Bunaken Sulawesi Utara. Jurnal LPPM Bidang Sains dan Teknologi, 2(2):7-8.

Brauer F. and Castilo-Chavez, C., 2000.

$\begin{array}{llr}\text { Mathematical } & \text { Model in } \\ \text { Population } & \text { Biology and } \\ \text { Epidemiology, Springer. } & \end{array}$

Cahyadi, R. 2009. Uji Toksisitas Akut

Ekstrak Etanol Buah Pare (Momordica charantia L.) Terhadap Larva Artemia salina Leach dengan Metode Brine Shrimp Lethality Test (BSLT). Skripsi. Universitas Diponegoro, Semarang.

Carballo, J.L., Inda, Z.L.H, Perez, P, dan Gravalos, M.D.G. 2002. A Comparison Between Two Brine Shrimp Assays to Detect In Vitro Cytotoxicity in Marine Natural Products. BMC Biotechnology, 2 (17):1-5.

Colin, L. P., and Charles A. 1995. Tropical Pacific Invertebrates: A Field Guide To the Marine Invertebrates Occuring on Tropical Pacific Coral Reefs, Seagrass Beds and Mangroves.

Diyabalanage, T., Ratnayake, R., Bokesch, H.R., Ransom, T.T., Henrich, C.J., Beutler, J.A., McMahon, J.B., and Gustafson, K.R. 2012. Flabelliferrins $A$ and $B$. sesquiterpenoids from the South Pacific sponge Carteriospongia flabellifera. J. Nat. Prod, 75: 1490-1494.

Fattorusso, E., Gerwick, W.H., and Taglialatela-Scafati, O. 2012. Handbook of Marine Natural Products. Springer.

Ghisalberti, E.L. 2008. Detection and Isolation of Bioactive Natural Products dalam Bioactive Natural Product: Detection, Isolation and Structural Determination. SEMNAS MIPA III UNDIKSHA.

Gunawan, I. 2007. Penapisan Awal Ekstraksi Senyawa Bioaktif Sebagai Antibakteri serta Uji Toksisitas dan Uji Minimum 
Inhibitory Concentration (MIC) dari Karang Lunak Asal Perairan Pulau Panggang, Kepulauan seribu. Skripsi. Fakultas perikanan dan IImu kelautan, IPB. Bogor.

Jiang, C.S., Muller, W.E.G., Schroder, H.C., and Guo, Y.W. 2012. Disulfide and Multi Sulfide-Containing Metabolites from Marine Organisms. Chem. Rev, 112:2179-2207.

Kornprobst, J.M. 2010. Encyclopedia of Marine Natural Products. WilleyBlackwell. Oxford. 1594(3).

Irma. 2017. Uji Toksisitas Daun Majapahit Crescentia cujete L. dengan Menggunakan Metode Brine Shrimp Lethality Test (BLST). Skripsi. Universitas Islam Negeri Alauddin. Makassar.

Mangindaan R.E.P. dan Taroreh R.Y. 2013. Pengujian Aktivitas Larvasida dari Ekstrak Ascidian Lissoclinum pattella Terhadap Larva Nyamuk Aedes aegypti. Jurnal Pesisir dan Laut Tropis, 3(1):13-17.

Meena, D. K., Sahoo, A. K., Swain, H. S., Borah, S., Srivastava, P. P., Sahu, N. P., \& Das, B. K. 2020. Prospects and Perspectives of Virtual In-vitro Toxicity Studies on Herbal Extracts of Terminalia Arjuna with Enhanced Stratagem in Artemia salina model: A Panacea to Explicit the Credence of the Solvent System in Brine Shrimp Lethality Bioassay. Emirates Journal of Food and Agriculture, 32(1):25-37.

Meyer, B.N., Ferrigni, N.R, Putnam, J.E, Jacobsen, L.B, Nichols, D.E, dan McLaughlin, J.L, 1982. Brine
Shrimp: A Convenient General Bioassay for Active Plant Constituents. Planta Medica, 45: 31-34.

Newman, D.J. and Cragg, G.M. 2012. Natural Products as Sources of New Drugs over the 30 Years from 1981 to 2010. J. Nat. Prod, 75:311-335.

Pawlik, J.R. 1993. Marine Invertebrate Chemical Defenses, Crem.1911-1922.

Pisut, D.P and Pawlik, J.R. 2002. Antipredator V Chemical Defenses of Ascidias: Secondary Metabotits Orinorganic acid- J. Experimental Marine Biology and Ecology, 27:203-214.

Priyanto. 2009. Toksikologi Mekanisme Terapi Antidotum dan Penilaian Resiko. Jakarta: Lembaga Studi dan Konsultasi Farmakologi, 156-160.

Priyatmoko W. 2008. Aktivitas Antibakteri Karang Lunak Hasil Transplantasi (Sinularia sp.) pada Dua Kedalaman Berbeda di Perairan Pulau Pramuka Kepulauan Seribu, Dki Jakarta. Skripsi. Fakultas Perikanan dan IImu Kelautan Institut Pertanian Bogor. Bogor.

Radhika P. 2006. Chemical Constituents and Biological Activities of the Soft Coral of Genus Cladiella: A review. Biochemical Systematics and Ecological, 34:781-789.

Suparno. 2005. Kajian Bioaktif Spons Laut (Porifera: Demospongiae) Suatu Peluang Alternatif Pemanfaatan Ekosistem Karang Indonesia dalam Bidang Farmasi Makalah Pribadi Falsafah Sains. Pascasarjana IPB, Bogor. 
Tanamatayarat, $\quad$ P. 2016. Antityrosinase, Antioxidative Activities, and Brine Shrimp Lethality of Ethanolic Extracts from Protium serratum (Wall. ex Colebr.) Engl. Asian Pacific Journal of Tropical Biomedicine, 6(12):1050-1055.

Widyastuti S, 2008. Uji Toksisitas Ekstrak Daun Iprih (Ficus glabella Blume) terhadap Artemia salina Leach. dan Profil Kromatografi Lapis Tipis. Skripsi Fakultas Farmasi Universitas Muhammadiyah Surakarta. Surakarta.

Werorilangi, S. dan Abdul, H. 2010. Uji Sitotoksisitas Ekstrak (Crude Extract) Karang Lunak (Octocorallia: alcyonacea) Dari Kepulauan Spermonde Kota 